\title{
A chimpanzee's (Pan troglodytes) long-term retention of lexigrams
}

\author{
MICHAEL J. BERAN, JAMES L. PATE, \\ W. KIRK RICHARDSON, and DUANE M. RUMBAUGH \\ Georgia State University, Atlanta, Georgia
}

\begin{abstract}
In this experiment, a chimpanzee's (Pan troglodytes) long-term retention was examined. The chimpanzee, Lana, was trained to use lexigrams (geometric symbols representing linguistic units) for foods, colors, and objects when she was 2 years of age. At the age of 27 , her recognition of three sets of lexigrams was examined. One of these sets (long term lexigrams) included five object lexigrams, one color lexigram, and one food lexigram, none of which had been seen by Lana for more than 20 years. The second set (different-referent lexigrams) contained lexigrams that are still present on current lexigram keyboards, but had been assigned new referents. The third set (same-referent lexigrams) contained lexigrams that had been kept on the keyboards Lana had used and that had retained the same referents. A food, a colored square, or an object was presented, and Lana had to select, by using a joystick, a lexigram on a computer screen. Lana chose the correct lexigram at a level significantly greater than chance for five of the seven lexigrams that she had not seen for more than 20 years.
\end{abstract}

Human subjects can retain information for variable lengths of time. They can retain, over a period of months and even years, course schedules and word lists (Healy, King, \& Sinclair, 1997; Wittman \& Healy, 1995), skills such as letter detection (Healy, Fendrich, \& Proctor, 1990; Proctor \& Healy, 1995) and data entry (Fendrich, Healy, \& Bourne, 1991), and even complex skills such as tank gunnery (Marmie \& Healy, 1995). They can also retain, for decades, information about people (Bahrick, Bahrick, \& Wittlinger, 1975), mathematics (Bahrick \& Hall, 1991), and foreign languages (Bahrick, 1984). For example, in an extensive experiment in which long-term retention of Spanish was investigated, Bahrick (1984) found that students who had learned Spanish in school but had subsequently ceased to use it showed a decrement in their retention of that language that proceeded exponentially for the first 3 to 6 years but then remained unchanged for periods as long as 50 years. This occurred even for individuals who reported never having rehearsed their Spanish in the interim. These students typically retained more vocabulary knowledge than grammar knowledge, and recognition performance was better than recall performance.

Research on human memory dates back to Ebbinghaus (1885/1964) but Gleitman (1971) noted that little experi-

This research was supported by National Institutes of Health Grant NICHD-06016 to the Language Research Center of the College of Arts \& Sciences, Georgia State University. The authors thank John Kelley, Charles Menzel, and Christopher Elder for their assistance in conducting experimental sessions with Lana. The authors also thank David Washburn and Charles Menzel for their comments on earlier versions of this paper. Correspondence concerning this article should be addressed to M. J. Beran, Language Research Center, Department of Psychology, Georgia State University, Atlanta, GA 30303 (e-mail: mjberan@ concentric.net). mental research has been done on long-term retention in nonhuman animals. Although anecdotal evidence regarding pets that remember past owners despite many years of absence and regarding the observations that migrating animals return to the place of their birth each year or at the end of their lives abounds, strict experimental testing of the long-term retention in animals is conspicuously absent. Some animals, such as the elephant, are reported to retain information about other elephants and about the locations of water holes and feeding sites that they must visit during periods of drought for long periods of time (Chadwick, 1992; Moss, 1988). Kohler (1917/1925) noted that the chimpanzees that he studied knew him immediately upon his return after a long absence; he also studied the chimpanzees' long-term retention of perceptual discriminations and of the locations of buried food items. However, these retention intervals for food locations were less than 2 days, and the retention for discriminations did not exceed 2 years. Are nonhuman animals capable of memory feats such as those of the people who retained for 50 years much of the Spanish they had learned (Bahrick, 1984)? We know of no previous experimental investigations in nonhuman animals that could be used to answer this question. What is known from systematic observations is that various species of nonhuman animals retain information for periods of time, ranging from hours to years. Typically, this retention is of spatial information or of learned discriminations.

In many of the research projects on long-term retention and spatial memory in nonhuman animals, foraging behaviors have been investigated. For example, various species of birds store food and then find it days and even months later (Balda, Bunch, Kamil, Sherry, \& Tomback, 1987; Balda \& Turek, 1984; Balda \& Wiltschko, 1995; Sherry, 1985; Shettleworth, 1992), although performance 
has been found to deteriorate with time in some studies (Bedenkoff, Balda, Kamil, \& Hile, 1997; Hitchcock \& Sherry, 1990). Four species of birds (Clark's nutcrackers, pinyon jays, scrub-jays, and Mexican jays) have demonstrated long-term memory for caches for as long as 285 days in experimental testing situations (Balda \& Kamil, 1992; Bedenkoff et al., 1997). Rats remember locations visited on a radial maze after several hours (Beatty \& Shavalia, 1980), although Gagne (1941) found retention deficits in runway performance of rats after intervals of 3, 7, 14, and 28 days. Menzel (1991) found that Japanese macaques (Macaca fuscata) formed hypotheses about active food sites after only one find at a site. The monkeys took into account the specific types of foods found and the types of locations that contained those foods in the past. These monkeys relied on information about past multiple finds of various foods in deciding where to search next.

Menzel (1999) also recently investigated long-term recall and reporting of information in a chimpanzee. In that experiment, a chimpanzee was shown an item (typically a preferred food) being hidden in an outdoor enclosure. Later, the chimpanzee, when indoors with uninformed caretakers, recruited the caretakers to come outdoors and retrieve the item. This occurred with imposed delays of up to $16 \mathrm{~h}$ between the time when the chimpanzee saw the item being hidden in the outdoor enclosure and the time when she could recruit a caretaker and return to the enclosure.

Nonhuman animals that have learned discriminations also retain information pertaining to those discriminations for variable periods of time. Schwarz, Feldman, and Susswein (1991) found evidence of long-term memory for learning in gastropod molluscs. Kraemer (1984) reported that pigeons retained for as long as 20 days discriminations that they had learned. Burdyn, Noble, Shreves, and Thomas (1984) found long-term memory for concepts in squirrel monkeys as well. These animals had been trained to make judgments of oddity and relative numerousness and were retested after periods as long as 5 years. These monkeys performed very well on the retest, which indicates that the relevant concepts were retained. Monkeys also demonstrated some retention of learning set behavior over a period of 6 years (Bessemer \& Stolnitz, 1971).

However, the question of whether any nonhuman animal is capable of long-term retention in excess of 20 years, such as that exhibited by the humans observed by Bahrick (1984), was not investigated in any of the nonhuman animal studies mentioned above. This is the result of two factors. First, few animals can be observed for that length of time, owing to the limits of life span. Second, when an animal is available for such a long period of time, the environment in which information is encoded and retained is difficult to control or specify. In the present experiment, one chimpanzee's (Pan troglodytes) retention of lexigram labels for foods, colors, and objects that she had not used, and in some cases not even seen, for more than 20 years was assessed. This retention, if evident, would indicate that animals other than humans may have the capacity for retention of information for intervals measured in decades.
In the 1970 s, investigators began to examine the acquisition and use of language by great apes. These projects involved the use of sign language with chimpanzees (Gardner \& Gardner, 1969; Terrace, 1979) and gorillas (Patterson, 1990), the use of plastic tokens as symbols by chimpanzees (Premack \& Premack, 1983), and the use of lexigrams (geometric symbols representing linguistic units) by chimpanzees (Rumbaugh, 1977; SavageRumbaugh, 1986). The first chimpanzee that was taught to communicate using lexigrams was Lana. Lana was placed in an environment in which all of her interactions with caretakers involved her use of a large computerized keyboard composed of lexigrams (Rumbaugh, 1977). Lana was required to produce grammatically correct sentences to achieve what she wanted. For example, when an apple was loaded in one of the food dispensers controlled by the computer, she would produce "PLEASE MACHINE GIVE PIECE-OF APPLE" to receive that food. She also could produce "PLEASE MACHINE MAKE WINDOW OPEN" to get a view of the outdoors, or she could produce "PLEASE TIM TICKLE LANA" to engage in a game of tickling with a caretaker. Lana's requests had to be both appropriate to the situation and grammatically correct in order for her to receive what she requested; she learned approximately 100 of these lexigrams (Rumbaugh, 1977).

When Lana was trained with lexigrams in the 1970s, a systematic investigation of her naming of six objects and six colors was undertaken (Essock, Gill, \& Rumbaugh, 1977). Lana was asked to give either the color lexigram name or the object lexigram name for projected photographs or for one of six objects painted in one of six colors. Overall, Lana gave the correct answer to "WHAT NAME-OF THIS" on $76 \%$ of the trials and the correct answer to "WHAT COLOR THIS" on $83 \%$ of the trials.

The research initiated with Lana came to a conclusion in 1977, and Lana was returned to the colony from which she had originally come. During that time, she had no exposure to the lexigrams. Lana was returned to the chimpanzee colony at the Language Research Center in the early 1980s. At that time, however, the lexigram system consisted of new lexigrams to which Lana had never been exposed (Savage-Rumbaugh, 1986). Some of her original lexigrams were no longer present on the keyboard, and she did not see those lexigrams again until the present experiment, during which she was again asked to name items with the appropriate food, color, or object lexigram. Only through remembering the correct lexigram label for these colors and objects could Lana correctly answer on a trial. To do this, Lana would have to remember lexigrams that she had not seen for more than 20 years.

\section{METHOD}

\section{Subject}

The subject in this experiment was a 27 -year-old female chimpanzee (Pan troglodytes), Lana. In addition to serving as the first subject in lexigram-based ape language research (Rumbaugh, 1977; Rumbaugh \& Gill, 1976), Lana also has been the subject of research on animal numerical skills (Rumbaugh, Hopkins, Washburn, 


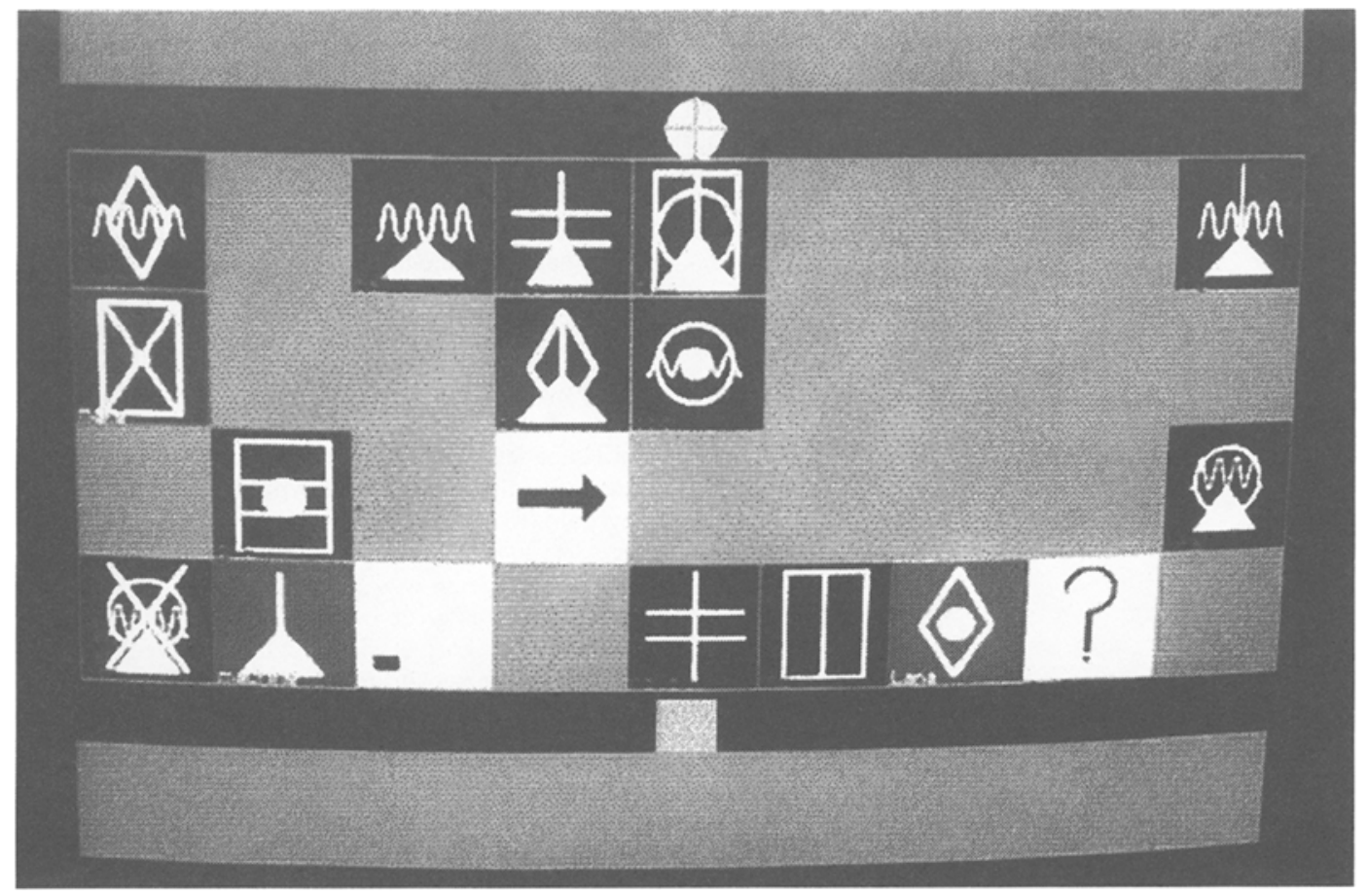

Figure 1. Lexigrams on the object keyboard. Row 1 (left to right): WHICH-IS, BALL, SHOE, BOWL, CUP. Row 2: MAKE, Box, COLOR. Row 3: gIVE, PLEASE, What. Row 4: CAN, MACHINE, PERIOD, NAME-OF, THIS, LANA, QUESTION. Lana controlled the cursor at the top of the screen; her selections were copied to the top row of the screen from left to right. The experimenter controlled the cursor at the bottom of the screen; his selections were copied to the bottom row of the screen from left to right.

\& Savage-Rumbaugh, 1989; Rumbaugh \& Washburn, 1993), color perception and classification (Essock, 1977), and delay of gratification (Beran, Savage-Rumbaugh, Pate, \& Rumbaugh, 1999), as well as having been a subject in other cognitive neuropsychological studies (Hopkins, Morris, Savage-Rumbaugh, \& Rumbaugh, 1992; Hopkins, Washburn, \& Rumbaugh, 1990; Morris \& Hopkins, 1993). She was housed in a building with 3 other chimpanzees and 1 orangutan, and she was maintained on a regular diet of fruit, vegetables, and protein supplements throughout the course of the experiment. Lana had extensive prior experience using a computer joystick to control a cursor on a computer screen in a variety of tasks.

\section{Apparatus}

Observations were conducted using a CompuDyne (Addison, TX) 386 computer with attached Seiko Instruments (San Jose, CA) monitor and Kraft Systems (Vista, CA) joystick. The program used involved three lexigram sets described below. The test items included foods, colored squares, and objects. The foods were apple, bread, chow (primate protein supplement), coffee, Coke, juice, M\&Ms, and milk. The colored squares were pieces of plastic $(10 \mathrm{~cm} \times 10 \mathrm{~cm} \times 1 \mathrm{~cm})$ painted one of six colors (black, blue, orange, red, violet, or yellow). The objects were a ball, a bowl, a box, a can, a cup, and a shoe.

\section{Design and Procedure}

At the beginning of each observation period, one of the three computerized keyboards was on the computer monitor screen. Experimenter 1 controlled the cursor at the bottom of the screen with a joystick and continued to have control until the lexigram PERIOD was selected. At that point, the cursor became inactive, and a sec- ond cursor at the top of the screen became active. That cursor was under the control of Lana, who used a second joystick attached to her cage to move the cursor. Her cursor remained active until she touched the lexigram PERIOD or until Experimenter 1 discontinued a trial. In order to select a lexigram, Experimenter 1 or Lana had to move the cursor into contact with the lexigram and pause for $1 \mathrm{sec}$. When Experimenter 1 selected a lexigram, a copy of that lexigram automatically moved to the bottom row of the screen. When Lana selected lexigrams, copies were placed at the top of the screen sequentially from the left to the right.

There were three conditions. In the first, foods were presented as the items to be labeled. In the second, colored squares were presented to be labeled, and in the third, objects. For each condition, a keyboard that contained only the lexigrams that made up the relevant response set and the lexigrams used to present questions to Lana was presented. For example, in the object-labeling condition, there were no food or color lexigrams on the keyboard. (The object lexigram keyboard is shown in Figure 1.) Eight foods were presented: apple, bread, chow, coffee, Coke, juice, M\&Ms, and milk. Six colored squares were presented: black, blue, orange, red, violet, and yellow. In addition to these six lexigrams on the computer keyboard, two other color lexigrams, GREEN and WHITE, were presented as foils for this condition. Six objects were presented: ball, bowl, box, can, cup, and shoe.

It is important to emphasize that Lana had not seen any of the lexigrams in their original form for more than 20 years. However, Lana had had daily access to other lexigrams representing other things since she had returned to the project in the 1980s. Some of these other lexigrams were similar to the lexigrams that she had learned in the 1970s. Therefore, only some of the lexigrams used in this experiment were valid tests of Lana's long-term retention. The 20 lexi- 
Table 1

Lexigrams for Test Items Separated into Three Categories

\begin{tabular}{llll}
\hline Category & Long-Term & Different Referent & Same Referent \\
\hline Foods & APPLE & & $\begin{array}{l}\text { BREAD } \\
\text { CHOW } \\
\text { COFFEE } \\
\text { COKE } \\
\text { JUICE } \\
\text { M\&MS } \\
\text { MILK }\end{array}$ \\
Colors & VIOLET & BLACK (strawberries) & \\
& & BLUE (hug) & \\
& & ORANGE (hello) & \\
& & RED (raisins) & \\
& & YELLOW (shot) & \\
Objects & BOWL & BALL (go) & \\
& BOX & & \\
& CAN & & \\
& CUP & \\
& SHOE & & \\
\hline
\end{tabular}

Note-Words listed in parentheses are the current referents for those original lexigram configurations that have different background colors in their current form. Lana has no comprehension of the current referents for these configurations (Beran et al., in press).

grams used in this experiment are listed in Table 1 and are classified as (1) long-term retention lexigrams, which were those that had not been present on the keyboard since 1977 in any form, (2) differentreferent lexigrams, which were those with the same geometric configuration but with a different referent and a different background color today than they had had on Lana's original keyboard, and (3) same-referent lexigrams, which were those with the same geometric configuration and the same referent but with a different background color today than they had had on the keyboard in the 1970 s. Only the lexigrams in the first category allowed an undisputed investigation of long-term retention for a period of time in excess of 20 years. The lexigrams in the second category might be appropriate for long-term retention evaluation because they had not been used in conjunction with the referents Lana had been trained to associate with them for more than 20 years. Lana was never trained to associate these lexigrams with their new referents, and there is no record of Lana using these lexigrams since her return to the Language Research Center in the 1980 s. Systematic computerized testing conducted in 1996 indicated that Lana did not know the new referents for these six lexigrams (Beran, Savage-Rumbaugh, Brakke, Kelley, \& Rumbaugh, in press).

At the beginning of a trial, Experimenter 2 entered the observation area with an item (a food, an object, or a colored square). That experimenter placed the item on a table next to the computer. Lana could see the item as it was being brought into the area, and it remained visible to her throughout the trial. Experimenter 1 could not see the item at any time during the trial. After placing an item on the table, Experimenter 2 remained standing next to the table but could not see the computer monitor. Experimenter 1 then asked Lana one of two possible questions. While presenting the question in lexigram form, the experimenter also spoke the question aloud. In the food and object-labeling conditions, the question was "?, WHAT, NAME-OF, THIS, PERIOD." The "?" lexigram was used as an indication to Lana that she was being asked a question, as had been done during initial training during the 1970 s. In the color labeling condition, the question was, "?, WHAT, COLOR, THIS, PERIOD." After Experimenter 1 completed the question, Lana had control of her cursor. In these observations, unlike in her learning of the lexigram system when she was younger, Lana was not required to produce grammatically appropriate sequences in response to the questions posed by the experimenter. Only single lexigram responses were permitted. This was designed to test Lana's recall of the lexigrams themselves rather than the grammar of her symbol system. As was noted earlier, human students typically retain more knowledge of vocabulary than of grammar (Bahrick, 1984).

When Lana selected one of the lexigrams, Experimenter 1 called out the lexigram only if it was from the appropriate response category (which consisted of only the lexigrams that were either food lexigrams when the items were foods, color lexigrams when the items were colored squares, or object lexigrams when the items were objects). Experimenter 2 indicated whether Lana's response was the correct label for the food, object, or colored square. When the lexigram that she selected was not from the appropriate category, it was ignored. For example, if Lana selected "WHAT," Experimenter 1 simply did nothing until Lana selected a lexigram that was from the appropriate response category. Only one categorical type of lexigram was present on a given keyboard (food, color, or object label), but other lexigrams that were necessary to frame questions were also present. When a category-appropriate lexigram was selected but was incorrect, no reward was given. Lana was given both rewards of preferred foods and verbal praise on some correct trials, but the reinforcement was intermittent. Some reinforcement was deemed necessary to sustain her attention to the task for the length of time that the testing required. Lana never received the food that she had named. No rewards were given for the first block of trials with colors or objects, but reward was given intermittently for the first block of trials with foods, which were used to teach Lana to use the current response system.

In the color- and object-labeling conditions, each of the colored squares and objects was presented as the item to be labeled on 10 trials, for a total of 60 object- and 60 color-labeling trials. Each food was presented as the item to be labeled for five trials. Only five trials were given, because seven of the eight food lexigrams were similar to the lexigrams on the keyboard used by apes at the Language Research Center today, and long-term retention was not evaluated with these lexigrams. Rather, these trials were given mainly to familiarize Lana with the keyboard and the testing procedure. The lexigram APPLE was evaluated as a long-term retention lexigram because it had not been on the keyboard since the 1970s, and it was presented during the same session as the other food items.

Items were presented in blocks of eight trials for the food-labeling condition, six trials for the color-labeling condition, and six trials for the object-labeling condition. The trials within a block were arranged randomly, with the constraint that each food, object, or colored square was used once in each block. More than one block was presented in each session, but the intertrial interval between the last trial in one block and the first trial in the next block was the same as the intertrial interval between trials within a block. There was no separation between blocks of trials, and thus, Lana could not have distinguished one block of trials from another. All food item testing was conducted in one session, and all colored-square and object testing was conducted in two sessions for each category (30 trials per session). The large number of trials in each session was used to exclude the possibility that Lana could use an elimination strategy on later trials in each block, as it allowed for some individual foods, colored squares, or objects to be presented in 2 consecutive trials or up to 12 trials apart. All trials with foods were presented first, trials with colored squares were presented next, and trials with objects were presented last.

\section{RESULTS}

The numbers of correct responses in the presence of each of the test stimuli (foods, colors, and objects) in the long-term retention test are shown in Table 2 . If it is assumed that by chance Lana would choose the lexigrams equally often, her performance was significantly greater than chance for all eight food lexigrams (all $p s<.01$, bi- 
Table 2

Lana's Performance with Each of the Stimuli

\begin{tabular}{|c|c|c|c|c|}
\hline Category & Stimulus & Performance & Incorrect Selections & Probability \\
\hline \multicolumn{5}{|c|}{ Long-Term Retention } \\
\hline Food & Apple* & $4 / 5$ & Coke (1) & .01 \\
\hline Color & Violet & $0 / 10$ & $\begin{array}{l}\text { Black (4), Blue (4), } \\
\text { White (1), Yellow (1) }\end{array}$ & 1.000 \\
\hline \multirow[t]{6}{*}{ Objects } & Bowl & $0 / 10$ & $\operatorname{Cup}(9), \operatorname{Can}(1)$ & 1.000 \\
\hline & $\mathrm{Box}^{*}$ & $10 / 10$ & & .001 \\
\hline & $\mathrm{Can}^{*}$ & $10 / 10$ & & .001 \\
\hline & Cup & $7 / 10$ & Can (2), Shoe (1) & .001 \\
\hline & Shoe* & $10 / 10$ & & .001 \\
\hline & \multicolumn{4}{|c|}{ Different Referent } \\
\hline \multirow[t]{6}{*}{ Colors } & Black $^{*}$ & $10 / 10$ & & .001 \\
\hline & Blue $^{*}$ & $10 / 10$ & & .001 \\
\hline & Orange & $2 / 10$ & Green (5) Yellow (3) & .52 \\
\hline & Red & $6 / 10$ & Black (1), Green (1) & \\
\hline & & & White (1), Yellow (1) & .002 \\
\hline & Yellow* & $10 / 10$ & & .001 \\
\hline Object & Ball $^{*}$ & $10 / 10$ & & .001 \\
\hline \multicolumn{5}{|c|}{ Same Referent } \\
\hline \multirow[t]{7}{*}{ Foods } & Bread $^{*}$ & $4 / 5$ & M\&M (1) & .01 \\
\hline & Chow & $4 / 5$ & Juice (1) & .01 \\
\hline & Coffee $^{*}$ & $4 / 5$ & Coke (1) & .01 \\
\hline & Coke* & $5 / 5$ & & .001 \\
\hline & Juice* & $4 / 5$ & Milk (1) & .01 \\
\hline & ${\mathrm{M} \& \mathrm{Ms}^{*}}^{*}$ & $5 / 5$ & & .001 \\
\hline & Milk $^{*}$ & $5 / 5$ & & .001 \\
\hline
\end{tabular}

Note-The numbers in parentheses indicate the number of times an incorrect lexigram was applied to a stimulus. ${ }^{*}$ Correct on the first presentation.

nomial test). These lexigrams were used mainly to teach Lana the response system, and it is clear that she learned the system quickly. Her responses to the black, blue, red, and yellow colored squares were also significantly greater than chance, which was estimated at .125 , including the foils GREEN and WHITE (all $p$ s $<.01$, binomial). Her responses were significantly greater than chance for the objects ball, box, can, cup, and shoe with chance estimated at .17 (all $p \mathrm{~s}<.01$, binomial). Lana's overall performance in this experiment was similar to her earlier overall performance (Essock et al., 1977). In the present experiment, Lana was correct on $63 \%$ of the color-labeling trials, but when the trials in which violet was presented were excluded (Lana was incorrect on all 10 of those trials), her performance with the colored squares was $76 \%$. In the previous experiment, as noted earlier, she was correct on $83 \%$ of the color-labeling trials (Essock et al., 1977). In the present experiment, Lana was correct on $78 \%$ of the object-labeling trials, whereas she was correct on $76 \%$ in the previous experiment (Essock et al., 1977). Unfortunately, performances with individual objects and colors were not given by Essock et al., so that comparisons of performance on each object and color cannot be made.

It is noteworthy that Lana used BLACK, BLUE, and YELLOW on $73 \%$ of the trials and used the remaining five color lexigrams on only $27 \%$ of the trials. Furthermore, Lana used BLACK and BLUE to respond to eight instances of violet; given that violet is in the blue end of the spec- trum and that it is relatively dark, her choice of BLACK and BLUE lexigrams is reasonable. Also, Lana used either the CUP or the CAN lexigram when the bowl was presented. Cups, cans, and bowls are containers and have similar shapes, so her errors in using those lexigrams and in responding to those stimuli may have been a result of generalization on the basis of shape or function.

Lana demonstrated long-term retention for some of the lexigrams tested. As is shown in Table 2, Lana's longterm retention was significantly greater than chance for five of the seven items in the long-term retention category. Of these five, Lana was correct on the first presentation of four of these (box, can, shoe, and apple; $p<.05$, binomial). She also correctly selected the different-referent lexigrams for the colors black, blue, and yellow, and for the object ball on their first presentations $(p<.05$, binomial). The effect of Lana's having seen those lexigrams with different referents should have degraded her performance when she was asked to use them in designating old referents (Spear \& Riccio, 1994). That her performance did not deteriorate indicates that Lana has continued to remember the original referents with which those lexigrams are associated.

In the food-labeling condition, on only 3 of the 40 trials did Lana select a lexigram that was not a food label prior to selecting a food label for evaluation. In the objectlabeling condition, Lana never selected a nonobject lexigram. However, in the color-labeling condition, Lana selected noncolor lexigrams first for 56 of the 60 trials. 
Of these 56 trials, 45 contained the lexigrams WHAT, LANA, or both of these and then a color lexigram. Although Lana used many more noncolor lexigrams than she used nonfood lexigrams or nonobject lexigrams, it is possible that she was using the lexigrams LANA and WHAT as part of each answer. This is not surprising, given her original training with sequences of lexigrams (Rumbaugh, 1977). Her use of other lexigrams did not interfere with her selection of lexigrams from the correct categories. These noncategorical selections were not evaluated as correct or incorrect, and after each of these selections, the probability of her selecting the correct categorical lexigram by chance remained the same.

\section{DISCUSSION}

Lana has retained knowledge of some of the original lexigrams that she learned when she was much younger and that she has not seen for more than 20 years. Lana's long-term retention was assessed most purely by using her responses to one food, one colored square, and five objects (i.e., the first seven items in Table 2). She was correct on the food item and four of the five object lexigrams at a level significantly greater than chance.

For the different-referent lexigrams, Lana also performed very well. The geometric configurations of those lexigrams have remained on the lexigram keyboards that are used at the Language Research Center, but both their referents and their background colors are different from the lexigrams on Lana's original keyboard. It is possible that those lexigrams may have served as reminders of their original meanings, but that is unlikely because there is no record of her having used those lexigrams. In the present experiment, Lana was correct on 46 of 50 trials $(92 \%)$ with the lexigrams for which there were new referents when she was presented with their old referents. Lana's selection of those same lexigrams when she was presented with their new referents (presented as photographs) was not significantly better than chance (Beran et al., in press). Thus, she has not learned the new referents of these lexigrams, and it seems reasonable to conclude that her performance in the present experiment indicates that she has retained the original meaning of those lexigrams during the 20 years in which she has not used them in association with their original referents.

Differences among the retention of the individual lexigrams is apparent. With some items, Lana's retention was perfect; with other items, her retention was substantial but not perfect; and with a few items, her performance was always incorrect. This is similar to findings with humans; some information is perfectly retained, some is retained imperfectly, and some is not retained at all (Bahrick, 1984).

In the present experiment, recognition memory was assessed. That is, all lexigrams from a specific category were present on each trial. Lana simply had to recognize the correct lexigram that she had learned to use in her earlier training with various foods, colors, or objects. Recog- nition tests invariably produce larger retention scores than recall procedures do (Bahrick, 1984; Postman \& Rau, 1957), and this was most likely the case here. Often retention decrements over time are the result of a change in the stimulus situation. This decrement occurs when learning is associative and when a subject learns under one stimulus condition but is tested under another. With an increasing retention interval, the probability of stimulus change increases. Retention, therefore, might have been greater if the original training had occurred under varying rather than constant stimulus conditions (Gleitman, 1971). In Lana's case, her original training did not occur under varying conditions; she remained in a cage with her computer apparatus for the duration of the experiment (Rumbaugh, 1977). The present memory test was performed in conditions that were vastly different from those in which she learned these lexigrams. During the present observations, she used a different means of selecting lexigrams (a joystick rather than buttons on a large computer apparatus), and she was not required to produce grammatically correct sentences in order to be rewarded. However, her performance was very good. Her performance may reflect the fact that Lana was raised in a strict learning situation but that she has lived in a less rigid environment regarding her use of lexigrams for most of her adult life. She continues to use the current lexigrams daily to request various things from caretakers, and she retains knowledge of the usefulness of lexigrams, in general, as a means of attaining things she wants. Her performance in this experiment indicates that her original learning of lexigrams also had a strong impact on her memory of those lexigrams, an impact that lasted for more than 20 years with no intervening exposure to some of these lexigrams.

\section{REFERENCES}

BaHRick, H. P. (1984). Semantic memory content in permastore: Fifty years of memory for Spanish learned in school. Journal of Experimental Psychology: General, 113, 1-26.

Bahrick, H. P., Bahrick, P. O., \& WitTlinger, R. P. (1975). Fifty years of memories for names and faces: A cross sectional approach. Journal of Experimental Psychology: General, 104, 54-75.

BAHRick, H. P., \& HALL, L. K. (1991). Lifetime maintenance of high school mathematics content. Journal of Experimental Psychology: General, 120, 20-33.

Balda, R. P., Bunch, K. G., Kamil, A. C., Sherry, D. F., \& Tomback, D. F. (1987). Cache site memory in birds. In A. C. Kamil, J. R. Krebs, \& H. R. Pulliam (Eds.), Foraging behavior (pp. 645-666). New York: Plenum.

BAlDA, R. P., \& Kamil, A. C. (1992). Long-term spatial memory in Clark's nutcracker, Nucifraga columbiana. Animal Behaviour, 44, 761-769.

Balda, R. P., \& TUREK, R. J. (1984). The cache-recovery system as an example of memory capabilities in Clark's nutcracker. In H. L. Roitblat, T. G. Bever, \& H. S. Terrace (Eds.), Animal cognition (pp. 513532). Hillsdale, NJ: Erlbaum.

BALDA, R. P., \& Wiltschko, W. (1995). Spatial memory of homing pigeons, Columba livia, tested in an outdoor aviary. Ethology, 100, 253-258.

BeatTy, W. W., \& Shavalia, D. A. (1980). Spatial memory in rats: Time course of working memory and effect of anesthetics. Behavioral \& Neural Biology, 28, 454-462. 
Bedenkoff, P. A., Balda, R. P., Kamil, A. C., \& Hile, A. G. (1997). Long-term spatial memory in four seed-caching corvid species. $A n$ imal Behaviour, 53, 335-341.

Beran, M. J., Savage-Rumbaugh, E. S., Brakke, K. E., Kelley, J. W., \& Rumbaugh, D. M. (in press). Symbol comprehension and learning: A "vocabulary" test of three chimpanzees (Pan troglodytes). Evolution of Communication.

Beran, M. J., Savage-Rumbaugh, E. S., Pate, J. L., \& Rumbaugh, D. M. (1999). Delay of gratification in chimpanzees (Pan troglodytes). Developmental Psychobiology, 34, 119-127.

Bessemer, D. W., \& Stollnitz, F. (1971). Retention of discriminations and an analysis of learning set. In A. M. Schreir \& F. Stollnitz (Eds.), Behavior of the nonhuman primates: Modern research trends (pp. 1-58). New York: Academic Press.

Burdyn, L. E., Jr., Noble, L. M., Shreves, L. E., \& Thomas, R. K. (1984). Long-term memory for concepts by squirrel monkeys. Physiological Psychology, 12, 97-102.

Chadwick, D. H. (1992). The fate of the elephant. San Francisco: Sierra Club Books.

EBbinghaUs, H. (1964). Memory: A contribution to experimental psychology. New York: Dover. (Original work published 1885)

Essock, S. M. (1977). Color perception and color classification. In D. M. Rumbaugh (Ed.), Language learning by a chimpanzee: The LANA project (pp. 207-224). New York: Academic Press.

Essock, S. M., Gill, T. V., \& Rumbaugh, D. M. (1977). Language relevant object- and color-naming tasks. In D. M. Rumbaugh (Ed.), Language learning by a chimpanzee: The LANA project (pp. 193-206). New York: Academic Press.

Fendrich, D. W., Healy, A. F., \& Bourne, L. E. (1991). Long-term repetition effects for motoric and perceptual procedures. Journal of Experimental Psychology: Learning, Memory, \& Cognition, 17, 137-151.

GAGNE, R. M. (1941). The retention of a conditioned operant response. Journal of Experimental Psychology, 29, 296-305.

Gardner, R. A., \& GARDNER, B. T. (1969). Teaching sign language to a chimpanzee. Science, 165, 664-672.

Gleitman, H. (1971). Forgetting of long-term memories in animals. In W. K. Honig \& P. H. R. James (Eds.), Animal memory (pp. 1-44). New York: Academic Press.

Healy, A. F., Fendrich, D. W., \& Proctor, J. D. (1990). Acquisition and retention of a letter-detection skill. Journal of Experimental Psychology: Learning, Memory, \& Cognition, 16, 270-281.

Healy, A. F., King, C. L., \& Sinclair, G. P. (1997). Maintenance of knowledge about temporal, spatial, and item information: Memory for course schedules and word lists. In D. G. Payne \& F. G. Conrad (Eds.), Intersections in basic and applied memory research (pp. 215230). Mahwah, NJ: Erlbaum.

HitchCock, C. L., \& ShERRY, D. F. (1990). Long-term memory for cache location in the black-capped chickadee (Parus atricapillus). Animal Behavior, 40, 701-712.

Hopkins, W. D., Morris, R. D., Savage-Rumbaugh, E. S., \& RumBAUGH, D. M. (1992). Hemispheric priming by meaningful and nonmeaningful symbols in language-trained chimpanzees ( $P a n$ troglodytes): Further evidence of a left hemisphere advantage. $B e$ havioral Neuroscience, 106, 575-582.

Hopkins, W. D., Washburn, D. A., \& Rumbaugh, D. M. (1990). Processing of form stimuli presented unilaterally in humans, chimpanzees (Pan troglodytes), and monkeys (Macaca mulatta). Behavioral Neuroscience, 104, 577-582.

Kohler, W. (1925). The mentality of apes (E. Winter, Trans.). New York: Harcourt, (Original work published 1917)

Kraemer, P. J. (1984). Forgetting of visual discriminations by pigeons. Journal of Experimental Psychology: Animal Behavior Processes, 10, $530-542$.
MARMie, W. R., \& HeAly, A. F. (1995). The long-term retention of a complex skill. In A. F. Healy \& L. E. Bourne, Jr. (Eds.), Learning and memory of knowledge and skills: Durability and specificity (pp. 3065). London: Sage Publications.

Menzel, C. R. (1991). Cognitive aspects of foraging in Japanese monkeys. Animal Behavior, 41, 397-402.

MENZEL, C. R. (1999). Unprompted recall and reporting of hidden objects by a chimpanzee (Pan troglodytes) after extended delays. Journal of Comparative Psychology, 113, 426-434.

MORRIS, R. D., \& HopkINS, W. D. (1993). Perception of human chimeric faces by chimpanzees: Evidence for a right hemisphere advantage. Brain \& Cognition, 21, 111-122.

Moss, C. (1988). Elephant memories: Thirteen years in the life of an elephant family. New York: Morrow.

Patterson, F. L. (1990). Language acquisition by a lowland gorilla: Koko's first ten years of vocabulary development. Word, 41, 97-143.

Postman, L., \& RaU, L. (1957). Retention as a function of the method of measurement (University of California Publications in Psychology, No. 8, pp. 217-270). Berkeley: University of California Press.

Premack, D., \& Premack, A. J. (1983). The mind of an ape. New York: Norton.

Proctor, J. D., \& Healy, A. F. (1995). Acquisition and retention of skilled letter detection. In A. F. Healy \& L. E. Bourne, Jr. (Eds.) Learning and memory of knowledge and skills: Durability and specificity (pp. 282-299). London: Sage.

Rumbaugh, D. M. (Ed.) (1977). Language learning by a chimpanzee The LANA project. New York: Academic Press.

Rumbaugh, D. M., \& GiLl, T. V. (1976). The mastery of language-type skills by the chimpanzee (Pan). In S. R. Harnad, H. D. Steklis, \& J. Lancaster (Eds.), Origins and evolution of language and speech (Annals of the New York Academy Sciences, Vol. 280, pp. 562-578) New York: New York Academy of Sciences.

Rumbaugh, D. M., Hopkins, W. D., Washburn, D. A., \& SavageRumbaugh, E. S. (1989). Lana chimpanzee learns to count by "Numath": A summary of a videotaped experimental report. Psychological Record, 39, 459-470.

Rumbaugh, D. M., \& Washburn, D. A. (1993). Counting by chimpanzees and ordinality judgments by macaques in video-formatted tasks. In S. T. Boysen \& E. J. Capaldi (Eds.), The development of numerical competence: Animal and human models (pp. 87-106). Hillsdale, NJ: Erlbaum.

Savage-Rumbaugh, E. S. (1986). Ape language: From conditioned response to symbol. New York: Columbia University Press.

Schwarz, M., Feldman, E., \& Susswein, A. J. (1991). Variables affecting long-term memory of learning that a food is inedible in Aplysia. Behavioral Neuroscience, 105, 193-201.

SHerry, D. (1985). Food storage by birds and mammals. Advances in the Study of Behavior, 15, 153-188.

SHETTLEWORTH, S. J. (1992). Spatial memory in hoarding and nonhoarding tits (Paridae). In I. Gormezano \& E. A. Wasserman (Eds.), Learning and memory (pp. 25-44). Hillsdale, NJ: Erlbaum.

Spear, N. E., \& Riccio, D. C. (1994). Memory: Phenomena and principles. Boston, MA: Allyn \& Bacon.

Terrace, H. S. (1979). Nim. New York: Knopf.

WitTMan, W. T., \& Healy, A. F. (1995). A long-term retention advantage for spatial information learned naturally and in the laboratory. In A. F. Healy \& L. E. Bourne, Jr. (Eds.), Learning and memory of knowledge and skills: Durability and specificity (pp. 170-205). London: Sage.

(Manuscript received March 23, 1999

revision accepted for publication September 21, 1999.) 